\title{
Youth Unemployment and Electoral Malpractices in Nigeria
}

\section{Monica Ewomazino Akokuwebe}

Department of Sociology

Faculty of the Social Sciences

Osun State University, Nigeria

DOI:10.36108/NJSA/7102/51(0190)

\begin{abstract}
In Nigeria, elections have been marred by various forms of malpractices in which youth often play prominent roles. The economic crisis and the accompanying structural adjustments in Nigeria have resulted in the alienation and marginalization of the youth, thereby exacerbating the whole phenomenon of youth restiveness. The National Bureau of Statistics reported that $42.24 \%$ of Nigerian youths were unemployed and 15.2 million youths remain unemployed in the economy in 2016. This unemployment scenario heightens the potential for violence and thus, political elites mobilize the pool of unemployed youths, often along ethnic, religious and party affiliations, as vital violent arsenals to manipulate and disrupt electoral processes. This paper, therefore, examines the nexus between electoral malpractices and youth unemployment in Nigeria. Guided by Rational Choice and R. K. Merton of Anomie theories, this paper argues that the present condition of massive youth unemployment is capable of engendering demographic dividends and national development. The paper concludes that to harness the advantages of a youthful population, the issue of unemployment should be accorded priority attention by among others creating the enabling environment for job opportunities. That way, youth are empowered and would less likely be involved in normless activities including electoral malpractices and violence.
\end{abstract}

Keywords: alienation, marginalization, youths, electoral malpractices

\section{Introduction}

Nigeria has become a conflict prone society where youths are the main actors of violent conflicts in previous elections. Although, the situation where the youths are the main perpetrators of electoral malpractice is not peculiar to the country, apprehension over the Nigerian situation is as a result of the enormity, complexity, regularity, consequences and apparent tendency of most electoral malpractices the country has witnessed since the reintroduction of democracy in 1999 (Momoh, 2000; Yau, 2000; Omeje, 2007).

Youths in Nigeria constitute a large proportion of the country's population (National Youth Policy, 2009; CIA, 2017). They are considered vulnerable in society because of the rapid pace of change they experience as a result of globalization, westernization, glued to mass media, involvements in conflicts, unemployment and poor self-development. Since the Post Cold Era, oil based revenues and its disbursements in the Niger Delta region has led to massive protests and violence among youths. This has given rise to youth militancy that plays out in nefarious activities such as attacks on oil firms, hostage taking, 
hijacking of oil workers, vandalization of oil pipes and detonating of bombs (Ukkiwo, 2007; Arowosegbe, 2009).

The history of elections in Nigeria from post-independence to year 2015 draws out the prevailing incidences of electoral malpractices and violence that has occurred involving the youths. Nevertheless, the first post-independence national election of 1964 and the 1965 western region election were concluded in the January 15, 1966 coup. The former was characterized by intimidation, chaos, fraud, degeneration of violent exercise in competitive and widespread rigging, which led to pervasive violence and inter-communal rioting that claimed more than 20 lives (Abubakar, 2015). This led to some of the major political parties deciding to boycott the election and creating in its aftermath serious constitutional dilemma. The latter election of the Western Region was also flawed by the problem of enormous rigging and other anomalies plus widespread violence, giving the spur for the first military coup in Nigeria and the culture of instability that was to plagued the country for over three decades (Abubakar, 2015; Amenaghawon, 2015).

Similarly, the 1979 elections that saw the emergence of Mallam Shehu Shagari as civilian president was criticized by international observers as having been massively rigged. The 1983 election, four years later was even worse, marred by corruption, political violence and polling irregularities. It provided another set of military adventures the impetus to seize power on December 31, 1983, citing electoral malpractices as one of its reasons for overthrowing the civilian government. The 1999, 2003 and 2007 elections, three elections conducted during this period of ten years of Nigeria's democracy have been ridiculed by many critics as far from free and fair as a result of tremendous irregularities which marred the elections. Perhaps, the freest and fairest election in the history of Nigeria was the June 12, 1993 election that was cancelled by General Ibrahim Babagida, former president of Nigeria (Abubakar, 2015).

Besides, the 1999, 2003 and 2007 general elections that brought President Olusegun Obasanjo and later, late President Umaru Yar 'Adua to power were marred by such pervasive violence and fraud. Prior to the advent of civil rule in 1999, studies (Momoh, 2000; Yau, 2000) have ascertained that Nigeria's economic crisis of the 1980's and the associated structural adjustment programme resulted in the alienation and marginalization of the youth, thereby aggravating the whole phenomenon of youth restiveness in general. Similarly, the 2011 elections was also climaxed into violence that initially started with widespread protests by supporters of the main opposition candidate, Muhammadu Buhari, of the Congress for Progressive Change (CPC), following the re-election of incumbent Goodluck Jonathan, who was the candidate for the ruling People's Democratic Party (PDP). This protests involving a large pool of youths, escalated into violent riots and sectarian killings in the Northern states of Adamawa, Bauchi, Borno, Gombe, Jigawa, Kaduna, Kano, Kastina, Niger, Sokoto, Yobe and Zamfara; where more than 65,000 persons have been displaced and lost their lives. The April 2011 
presidential election has no doubt further divided the country along ethnic and religious positions (Ladan-Baki, 2016).

In addition, the 2015 general elections in Nigeria experienced electoral violence and malpractices especially in the South-south part of Nigeria where different levels of mayhem and destruction of lives/properties occurred. On the other hand, the Northern and South Western states, witnessed minimal electoral violence unlike previous years where violence was more in the North. Notedly, other technical hitches were recorded such as lack of understanding among INEC, ad-hoc staff having poor knowledge of the need to remove film covering from the screen of the device which facilitates better finger print decoding, to the outright malfunction or failure of the card readers. Reverting to the old system of manual accreditation was as a result of card reading challenges which may have involuntarily opened the road map for electoral malpractices which is yet to be fully analysed (Amenaghawon, 2015).

However, with the advent of civil rule (1999-2015), the rise of electoral malpractices and youth restiveness in general, is yet to be done in understanding the connection between youth involvement in electoral malpractices and high rate of unemployment. The following questions arise: in the Nigerian democratic context, are electoral malpractices an unavoidable practice as a result of youth unemployment in Nigeria? What role has Nigeria government played in preventing high incidence of electoral malpractices in the past sixteen years of democratic rule in Nigeria? What categories and characteristics of youths are involved in electoral malpractices? What are the factors responsible for such involvement in malpractices especially in the electoral process?

Against this background, the paper argues that unemployment of youths is a motivation for them to be mobilized by political elites for electoral malpractices and violence in order to make ends meet. Therefore, the critical examination of the theoretical discourse of the nexus between youth unemployment and electoral malpractices is an imperative for government and non-governmental stakeholders to create vocational and employment institutions that will developed and make them employable. This will lead to positive behavioural change towards the consequences of electoral malpractices and the dividends of consolidated electoral processes free from malpractices. This paper also seeks to contribute to the growing discourse on the tasks youths are assigned to during election exercises so as to make a robust contribution towards the consolidation of democracy, free and credible future elections in Nigeria.

\section{Youth Unemployment Trend Overview}

Youth unemployment is a crucial problem in Africa and other developing countries and is estimated to be twice more than unemployment among adults (Simiyu and Lenah, 2012). Kararach, Hanson and Leautier (2011) stated that Africa is facing a youth bulge. According to ILO (2013), 90\% of the global youth population lives in developing countries thus posing an undermining 
challenge. The global unemployment rate averages $12 \%$ and the unemployed youth reaches about 75 million. This is an alarming global trend.

Most of the African countries rates of youth unemployment go above the global average rate of $12 \%$. For instance, Sierra Leone shows the highest rate of $60 \%$. In Nigeria, in 2012, the unemployment rate of the entire population is $23.9 \%$ while the unemployment rate among the youth is $37.7 \%$ (Araya, 2012). However, urban youth unemployment remains a major challenge for Africa and large, swelling African cities are awful places (Sommers, 2003). UNESCO (2003) states that youth unemployment has its own unique problems and the programs and schemes designed to help young people find jobs have inherent advantages and disadvantages. A number of strategies ought to be developed to help the youth out of unemployment but such efforts have not made meaningful impact in reducing unemployment.

There are youths who are qualified and able-bodied young persons but fail to get jobs at the prevailing wage rates. Such involuntary unemployment arises mostly in developing countries such as Nigeria and is a product of coordination failures. It can be regarded as unemployment caused by deficiency of effective demand for labour. Coordination failures also result from the disconnection that exists between universities and industries (Mago, 2014). More so, technological unemployment results from a shift labour-intensive to capitalintensive production systems. Some critics have advanced that technological unemployment has led to massive global unemployment especially among young people (Jubenkanda, 2003). Hi-tech production systems have replaced non-skilled workers. In the agricultural sector, the use of machinery has reduced the need for large numbers of workers needed for planting, weeding, watering and harvesting.

Human labour is fast getting replaced by better productive methods hence throwing millions of people into unemployment situations (Mago, 2014). Demand efficiency unemployment results from a situation where the demand for goods declines thus forcing manufacturers to downsize their operations. As a cost-cutting strategy, they will reduce the labour force thus creating unemployment. Structural and cyclical unemployment are viewed from an economic theory perspective as disequilibrium scenarios (Sembonja, 2007). Since they imply excess supply of labour on the labour market, the causes of this category of unemployment could be determined as lack of employability, inadequate job creation and lack of entrepreneurs.

Structural unemployment can be explained by the mismatch theory. The theory argues that failure of coordination between the educational institutions and industry creates a permanent skills gap that makes school leavers unemployable. Lack of employability reveals that young school-leavers do not have the skills required for labour market. However, structural constraints are faced by first time job seekers since employers opt for the experienced employee (ILO, 2012). The educational system in Nigeria does not adequately prepare school-leavers for the job market and school-leavers lack relevant education and training that allow them to fit into the labour market (Usoro, 
2010; Diana-Abasi, 2015). Cyclical unemployment is caused by business cycles where business activity decreases, productivity will decline hence causing layoffs.

Conversely, employment increases when there is a business boom. During the recession phase of the business cycle, cyclical unemployment occurs. For instance, during the Great depression of the 1930s, cyclical unemployment reached about 25\%. However, frictional unemployment results from job changes. When a worker moves from one job to the next, there will be a time when such worker will be temporarily out of employment. It also includes young people who are hunting for their first jobs - the time that elapses when moving from college/university to the first job. Frictional unemployment is regarded to be an inevitable and, at least in part, desirable that workers will be moving to take up better jobs (Jubenkanda, 2003).

According to ILO (2010), young employees are the last as employers prefer the experienced ones, and they are the first to be sent out of the jobs as employers prefer to keep adult employees (ILO, 2010). This becomes traumatic for youth and job scarcity affects them in most cases (ILO, 2013) which make them most vulnerable in the labour market. The UN News Centre (2013) warns in its report titled: "World's Youth Facing Worsening Unemployment" that the world's youth is becoming more vulnerable and the youth unemployment rate is increasing from year to year. ILO (2013) confirms that the world youth unemployment rate is currently at $2.4 \%$ and this disconnects the youth from the society. Notedly, disconnected youth are neither employed nor in education and this have serious consequences on national development. For such youths are likely to be recruited for electoral malpractices and armed conflicts in order to make ends meet.

\section{Youth's involvement in Electoral Malpractices in Nigeria}

Youth consistently, is a delicate phase in human development. It is the time when future choices are made. It represents the most volatile, complex, unpredictable, dynamic as well as the most vulnerable segment of the population, socio-economically, emotional and otherwise (Inokoba and Maliki, 2011). Youth refers to a young person between childhood and adulthood. It is for this reason that several institutions, agencies and countries, in defining youth, puts it within a certain age bracket, meaning that youth is a matter of age. It is general known and acceptable fact that youths are indispensable and dynamic quota of the population of any nation that incubate, and seen as the driving force for innovation, change and progress in any economy of a nation. No society can harness the demographic dividends and advancement of a growing economy, if its youths are not well invested upon, empowered and engaged. Their immense energy and drive must be tactfully packaged and

directed towards playing a constructive role in the process of governance, economic growth and development of the society (Inokoba and Maliki, 2011). 
However, the concept of youth has been subjected to diverse interpretations and flexible usage. At one level, the youth are conceptualized in terms of their futuristic role as leaders of society. Conversely, interrogation of the youth as a category, Obi (2006) aptly noted that the categorization of the youth as future leaders assumes the non-interrogation of the existing power relations in the society. This has become a recipe for preparing youths to maintain a particular mode of power relations that suggest a stability of structures of dominance and interests, but with the entry and exit of the occupants' overtime. On the other hand, this conceptualization also suggests the sub-ordination of youths to the power structure controlled by elders in order to facilitate system stability, cohesion and continuity.

Political time then becomes a conveyor belt that takes the loyal and disciplined youth into future power, when the elders pass into myth and history. Thus, the danger with the categorization of the youth in terms of their futuristic role as leaders is that, it implicitly relegates the role of the youth as social agents (Momoh, 2000). At another, the youth may also be categorized as the younger generation associated with protests, social revolutions or violent change. In this case, the youth become associated with energy, activism, sacrifice and ever ready to work for social transformation as a guarantee for a better and secure future (Obi, 2006). This interpretation of the youth captures the popular youth movements of the 1960's in the heady days of the civil rights movements in the United States, the pro-democracy demonstrations of June 1989 at the Tiananmen Square in Beijing, China and the more recent antiglobalization movements which have all been at the vanguard of the movement for change.

On the one hand, the youth can be engaged in violence or criminality particularly in the context where they are victims of social decay, manipulation or exclusion from the distribution of resources and opportunities in society (Blackwell and Duarte, 2014). In other contexts, the place of youths within a given mode of production and their access/non-access to the social surplus influences their politics. It is also important to understand that for some youths particularly in the poverty stricken economies of the developing world, Nigeria inclusive, what is paramount is survival. They must first of all survive before they can begin to think of fighting for a future. Indeed, as Obi (2006) noted that the very fact of survival is embedded in conflict, and then, the struggle for survival for the future is ambushed by more violence that pulls in young people into the tidal wave of class, ethnic, generational, communal and political agendas.

Over time, Nigerian youth has been fully involved in the ugly phenomenon of electoral malpractices and these have negative implication for democratic consolidation in Nigeria. Nigerians have acquired a culture of electoral violence from the engagement in electoral malpractices and has become part of the political culture in Nigeria such that all elections since independence (Nigeria has conducted nine general elections since independence in 1960, the elections were held in 1964, 1979, 1983, 1993, 1999, 2003, 2007, 2011 and 
2014) are virtually violence ridden. All of these elections were substantially marred by various types of violence associated with party politics, electoral malpractices and conduct of elections (Agba, 2011; Awopeju, 2011). The most disconcerting aspect of this issue is that youths who are the future leaders of the nation, are the main perpetrators and at the same time, the victims of electoral malpractices which often resulted into loss of lives.

Youths as nexus with the future are the pillars of human continuity. And this is where the contradiction is: we sacrifice the future by not properly inculcating and engaging them constructively in useful areas. In Nigeria, the roles most youths perform in the political and electoral process is violent in nature. And in most instances, these violent roles are assigned to them by political elite classes that have deliberately refused to imbibe and practice required democratic norms, values and tradition of fair and credible elections. Youths are vulnerable instruments of electoral malpractices and violence as a result of dislocated and poor parental background, poor education, unemployment and under employment, moral depravity and as well as political manipulations by selfish political elite class.

\section{Category and Characteristics of such Youths involved in Electoral Malpractices}

The United Nations conceptualized youth as the range of people between 18 and 24 years of age and has placed the age of 24 years as the upper limit while the Common Wealth Organization has put the upper limit of age of the youth at 29. However, there are emerging trend in some communities in Africa that indicate people in their 30's and sometimes 40's, still see themselves as youths when they should normally be considered adults owing to the fact that they are unemployed and unmarried.

Increasingly, youth identity in contemporary Africa has become synonymous with unemployment and poverty, in which young people continue to depend on their parents or relatives; making them in many respect adult youths (Obi, 2006). It also explains why such youths are available to be exploited by older people to act as perpetrators and victims of the production of violence. Referring to this social category as extended youths, Gore and Pratten (2003) perceived them as being defined irrespective of actual age, through economic and social circumstance and little prospect for future advancement. Similarly, the conception of the youth reflected in the work of Wyn and White (1997) reveal the rethinking of the youth in relational terms rather than age terms. That is, this focuses on the way youths are constructed through social institutions which are determined by social, cultural, political and economic specificities rather than solely by age or the experience of being young alone.

However, twenty million Nigerian youths are unemployed and they are security threat to the nation. Unemployment figure estimated at $41.6 \%$ was about the highest in the world noting that lack of employment opportunities coupled with a sense of hopelessness makes the youth susceptible to violence, crime, and terrorism (Umoru, 2015). Besides, the medium-to long-term impact 
on national productivity that the high rate of unemployment portends real and present danger to the sanctity of the country. This figure in Nigeria was well above the $25 \%$ average rate for North Africa and the Middle East which have been rocked by civil unrest largely spearheaded by unemployed youths in those regions (Umoru, 2015). There are clear imitations of this situations happening already in Nigeria, given the role of the youths in the 2011 post-election violence and the increasing incidence of religious extremism typified by the Boko Haram menace.

More so, youth involvement in electoral malpractices in Nigeria has taken a centre stage in the activities of political thuggery. The activities of electoral malpractices and thuggery are not noticeable in only one party but are seen in all political parties experienced everywhere in the country. For instance, Lawanti (2009) reported that in the Northern part of Nigeria, Karare is a brand of Hausa word referring to a group of people, mostly youth between the ages of 8-35 years, some of them are in secondary schools or school drop-outs. These youths are used by politicians during campaigns and elections in some sections of Northern Nigeria to intimidate voters and political opponents into accepting the position of their sponsors. They are violent, unemployed and mostly drug addicts. Similar group exists in Kano known as yandaba. In Kaduna, they are called Kawayeor yan mage while in Borno, they are known as ecomog, and in Bauchi, they are recognized as sarasuka. In Lagos, south western Nigeria, they are called area boys.

Such instances like the Kalare phenomenon in most Northern states is used first by the opposition to check the winning line of an incumbent who in most cases has a relative advantage of having the state machinery in his hands. In Kano, there is a long history of political thuggery that has occurred in Gombe between Goje and Hashidu in 2003 and 2007 elections. The sara-suka phenomenon in Bauchi, all have origin from the efforts of an opposition to defeat the incumbent governor (Lawanti, 2009). Historically the yanakusa, now called yandaba or banga, in Kano were used in the First Republic by the Northern Peoples' Congress (NPC) to check the winning streak of Northern Elements Progressive Union (NEPU). And today as it spreads to other states, the same reason that saw the beginning of yanakusa in Kano could be said to be the reason why the sara-suka groups were formed for instance in Bauchi, or Kalare in Gombe.

The sarasuka in Bauchi were formed by the supporters of Isa Yuguda to counter Governor Muazu's use of government machinery to stop Yuguda from contesting. However, Governor Isa Yuguda claimed that he inherited the sarasuka problem from the previous regime (Lawanti, 2009). The account of facts is similar in Borno state where ecomog groups in Borno were formed by the supporters of Ali Modu Sherrif to counter the incumbent governor's opposition to Sherriff's bid for the governorship of the state. The activities of the Kalare groups in Gombe became manifest when the opposition party People's Democratic Party (PDP) wanted to snatch power from the incumbent party All Nigeria People's Party (ANPP) in 2003. In fact, it was a tug of war between the 
two groups in 2003 and 2007 (Lawanti, 2009). Thus, these segments of the Nigerian population are supposedly to be the leaders of tomorrow but get involved in electoral malpractices to make ends meet. Little or no effort has been made to address the unemployment situations faced by the youths, which is one of the major root causes of conflicts.

\section{The Factors responsible for such involvement in Malpractice especially in the Electoral Process}

Contemporary Nigerian politics is characterized by thuggery in electoral malpractices and private armies of politicians which only serve to facilitate criminal victory at the polls. Since elections and post-elections periods of 1999 to 2014, a lot of states in Nigeria have witnessed electoral malpractices, political violence, killings and thuggery. These periods are characterized by what Agbaje, Onwudiwe and Diamond (2004) described as allegations of rigging, incidence of violence and litigations over elections outcomes in an increasingly charged atmosphere.

The flaws of electoral act in most countries constitute a serious threat to democratic values in any liberal democracy and they are integral in most African states Electoral Acts. Countries experiencing flaws of the Electoral Act are Kenya, Zimbabwe, Sierra-Leone and Nigeria. These flaws have affected Nigeria democracy over the years and the roots of democracy were yet to sprout. Some of the factors that are responsible for youth's involvement in electoral malpractices include but are not limited to the following:

1. Issue of security and peaceful elections: National security can be expressed as freedom from hunger, or from threat to a nation's ability to protect and defend itself, promote its cherished values and interest, and enhance the well-being of its people. The absence of continuous improvement in the socio-political and economic well-being of the people and their states are tagged insecurity (Oriakhi, 2012; Ali, 2015). When the political, social and economic well-being of the youths is not secured, it can constitute a threat to national security which often results to electoral conflicts and killings.

2. Electoral insecurity: This is critical to the success of the electoral process and no electoral management body can conduct successful elections if the security environment is polluted or violent. A political culture where votes do not count and where national dialogue is abhorred, and the people's sovereignty is regularly subverted, is one that cannot build security or set a pattern for development. In this atmosphere, youths are easily lured to cause violence in the election grounds.

3. Lack of internal democracy with the political parties: The major cause of election-related violence involving youths is the absence of internal democracy and lack of commitment to party rules. Most often, conflicts crop up when the people are not allowed to choose their candidates at the level of party primaries. Once, an imposed candidate from the level of party primaries are the people's choice, the opposition party members will 
involve the youths to start rigging elections, right from the primaries to the main elections.

4. Indiscriminate use of inciting statements by political actors: Language, body and verbal communication from a candidate of an election can encourage youth to partake in election malpractice through violence. Campaign speech similar to hate speech is usually made by political stakeholders and tailored towards instigating youths to get involved in violence against political opponents. Classical example of such contribution of indiscriminate use of inciting statements that causes violence and killings in the Northern Nigeria is the 2011 post-election violence.

5. The role of media in youth involvement in electoral malpractices: Youths are more glued to media such as the social and electronic media. The press can contribute to electoral malpractices through electoral violence by producing publication that contains inciting statements, which are freely made by candidates; and call-in contributors such as youths to live shows and the use of exaggerated and screaming banner headlines in print media.

6. Thuggery by political supporters: Party thugs and party workers are mostly identified with the youths of the different respective parties in Nigeria. They are mostly used by the party loyal follower for electoral malpractices, political violence and criminal activities for token sums. A lot of youths get themselves involved in the activities of the political thugs which include violation of the secret ballot, ballot stuffing, tampering with voting machines, fraudulent tabulation of results, and use of physical force or verbal intimidation at polling places.

7. Youth unemployment remains a major challenge for Africa, as it leads to unwanted outcome such as crime, hooliganism, poverty, violence, juvenile delinquency, substance abuse, stress and depression, suicide, family instability, lack of self-esteem, HIV/AIDS and other related problems.

8. Other factors that make youth to get involved in electoral malpractices are poor education or defective educational systems, lack of skills among the youth, lack of work experience, and unwillingness of youths to work. Formal and informal sector have failed to create enabling and employable environment for youths.

\section{Theoretical Framework}

This study is anchored on the Rational Choice Theory (RCT) and R. K. Merton Theory of Anomie - two sociological perspectives that emphasizes on the dimensions of human actors to make and reconstruct their actions on the basis of their evaluation of the milieus and the likely benefits that would be amass from their actions.

\section{The Rational Choice Theory}

The Rational Choice Theory, for instance, describe the process of determining what options are available and then choosing the most preferred one according 
to some consistent criterion. This starts with the idea that individuals have preferences and choose according to those preferences. The first task is to formalize what that means and precisely what it implies about the pattern of decisions we should observe (Levin and Milgram, 2004; Cramer, 2010).

However, the phenomenon of a demographic youth bulge may represent a set of social problems. It may be associated in some contexts, especially those with few labour market opportunities to absorb school-leaving youths, which makes them to choose from the available options for survival. The implication is that large number of youths is vulnerable to appalling working conditions, to unemployment, under-employment, to poor health and premature death, to violence and to extreme poverty. Unemployment is a major root cause of youth's agitations and their involvement in lawless activities. To achieve the demographic dividend, is to create labour market and economic policies that will provide job opportunities and enabling environment for youths.

Rational choice asserts that human beings behave rationally, either in the narrow sense of rational self-interest, or in the broader logic that decisions are rationally based on preferences (Hooker, 2011). This explain how human behaviour resulted from rational choices youths make, particularly in an economic context. Youths identifies themselves with the rationality of being rational with rational self-interest. The share cohorts of youth population have few licit earning opportunities, especially when society was characterised by a high share of 'direct material rewards'. And this would predispose such segment of the population to a high risk of their participation in electoral malpractices.

The violent behaviour among the youth as a result of electoral malpractices could be linked to social reality of issues that are affecting them and they include relative deprivation, rising expectations, frustration and aggression (Anifowose, 1982). The argument here is that aggression and violence among the youth is as a result of their unmet needs. The political elites seize this opportunity to manipulate and mobilize these frustrated and unemployed youths to perpetuate electoral malpractices and violence in the pursuit of their individual interests. The negative role youths play during election process is associated with massive economic decline. Various economic policies of adjustment have not fully addressed the issues of unemployment among youth population over time. And as such, youths are liable to electoral malpractices and violence for means of survival.

\section{R. K. Merton Theory of Anomie}

R. K. Merton Theory of Anomie which has been adopted as a complementary model for explaining the involvement of unemployed youths in electoral malpractices and the likely attempt at the social structure, culture and deviant behaviour shares similarities with Rational Choice Theory in many respects. The types include conformity, innovation, ritualism, retreatism and rebellion. The most common mode of adaptation is that of conformity. The actor accepts both the cultural goals and the institutionalized means for pursuing these goals. 
The connexion between unemployment and youth conformity to their present situation, apparently is organized round electoral malpractices (Adebayo, 2013). This explains the breakdown of social norms of electoral processes and these norms can no longer control the activities of the youths.

However, central to different versions of anomie theory is the premise that humans are normative beings. People act and think on the basis of commonly shared definitions and traditions of the society and within the environment they found themselves. To a greater and lesser extent the common meanings that emerge in social life have sentimental value for people that constitute morality and ethics. Thus, shared cultural values define and sanction people's goals and the means they use in reaching those goals and anomie marks the power of social values which regulate the ends and the means of human conduct, however is weakened (Merton, 1938; Bernburg, 2002; Messner, 2014).

Opportunities to reach cultural success goals through legitimate means vary by class position. Specifically, those in the lower classes are not awarded the same chances as those in the higher classes to pursue success in the acceptable ways. It is precisely this disjuncture between features of social structure and elements of culture that undermines the integrity of the culture and leads to anomie (Merton, 1957). The social structure strains the cultural values, making action in accord with them readily possible for those occupying certain statuses within the society and impossible for others. This structure acts as a barrier or as an open door to cultural mandates. When the cultural and the social structure are mal-integrated, the first calling for behavior and attitudes, which the second precludes, is a strain toward the breakdown of norms or toward normlessness (Merton, 1968). Without addressing unemployment problems among youths, they will be recruited though form of deception of providing better opportunities for them. And this will not be able to aid them to find their place in the society.

\section{Implications for Unemployment and Youths Involvement in Electoral Malpractices}

Unemployment and poverty, as social problems, have remained a long time major developmental challenges facing the youths in Nigeria. Obadan and Odusola (2001) noted that unemployment in Nigeria was more acute in the 1980 s and this has been on the increase ever since. In 2008, 15\% of the nation's work force was unemployed and in 2011 the figure rose to $20 \%$ (Lamido, 2013) and the victims of this phenomenon are the youths who till date have had the highest unemployment rate in Nigeria. The country's unemployment rate grew from $10.4 \%$ to $12.1 \%$ in year 2015 and a total of 15.2 million were either unemployed or underemployed in year 2016, representing youth unemployment rate of $42.24 \%$ (NBS, 2016). In Nigeria, unemployment varies by age group, educational level and sex classification.

Conversely, majority of these youths are paraded by the law enforcement agencies before the mass media as defaulters of electoral process and members of criminal groups fall within this age cohort of 15-35 years (Abba and Imam, 
2016). Most of those used in suicide bombings by terrorist groups in the country also fall within this age group. While those involved in the Niger Delta militancy are also of this age group (Human Rights Watch, 2003). The fact is that if these youths have alternative means of livelihood or are gainfully employed in the economy, most of them would not take part in these electoral malpractices and other criminal activities. Akande and Okuwa (2009) pointed out that, the unemployment challenge is captured by the growing number of unemployed youths roaming the streets of Nigeria.

This negative impact has attributed to poverty and rising crime wave which are consequences of this phenomenon. In other words, unemployment in Nigeria carries with it a number of attendant social, economic, political, malpractices in electoral processes, psychological and security challenges (Okafor, 2011). Yet, unemployment, electoral malpractice, violence, security, and poverty are the biggest problems facing most nations of the world. They are impediments to social progress, and lead to waste of human and material resources. However, security strategies remain incomplete if poverty and unemployment issues are not addressed.

Political violence, ethno-religious conflicts and terrorism rife in Nigeria today are no doubt consequences of unemployment and poverty. On the other hand, if most of our youths are employed, there would be drastic reduction in the level of their involvement in electoral malpractices, crime and insecurity in the country. A large number of the nation's youth are unemployed and the employed are very poorly remunerated and have large number of dependents which poses a great challenge for the electoral processes, good governance and national security of Nigeria.

\section{Conclusion}

From all indications, unemployment is a social menace in Nigeria and constitutes a serious threat to electoral process of the country. Obviously, unemployment creates poverty and poverty leads to insecurity. It therefore follows that unemployment has implications for national security. This is because unemployed youths could be manipulated to undermine national stability and cause violent disorder in the country as a result of their participation in electoral malpractices.

In addition, the greatest threats to national stability and security, is the largest segments of unemployed youth. Moreover, the present graduate unemployment in Nigeria is over $50 \%$ while $70 \%$ of the Nigeria population is leaving less than $\$ 2$ (two dollars) per day, which has increased youths' participation in electoral malpractices that have led to the general insecurity and rising crime wave across the country. National security centres directly on the development of a country owing to the fact that a greater segment of the youth population can lead to greater development. If strategic development policy is created to tackle the demographic challenges amongst the youths, in Nigeria, then the country will truly harvest the dividends of that greater segment of the Nigeria population. 
In conclusion, youth's population fall in the greater share of working age cohorts (Akokuwebe and Okunola, 2015) and demographic window of opportunity demanded from youths are the right skills and aptitude for employability. Thus, creating enabling environment and investing in economic opportunities are crucial in achieving the demographic dividend of bulging youth cohorts for sustainable development of Nigeria.

\section{Recommendations}

Based on the findings of the theoretical discourse of this paper, the following recommendations are made:

1. By ensuring independent alliance through constructive socialization and involvement of the youths in electoral processes.

2. Youths should be economically empowered through sincere, participatory and youth oriented skill acquisition.

3. Youths could be empowered socially through civil orientation and education to enable them to understand their roles in building the economy of the nation since they form the large percentage of the economically active population in Nigeria population pyramid.

4. The strategy of educational counseling, meaningful political socialization and constructive participation in elections involving the youths should be emphasized.

5. Political consciousness should be embedded in formal and non-formal education curriculum for the youths, thereby exposing them to deeper insights in knowing and defending their fundamental rights as citizens of this country.

6. Awareness campaigns should be provided and getting the youths involved in such campaigns that they are the potential leaders of tomorrow and such campaigns should centre more on the slogan "No political ambition is worth their blood and future".

Furthermore, youths should be exposed to peace education thereby, using the medium to rectify the culture of electoral malpractices, violence and aggression in order to inculcate the value of peaceful coexistence and non-violent groups during election exercises conducted in the country.

\section{References}

Abba, A.S. \& Imam, M. (2016) The role of youths in electoral processes: an appraisal of the Nigerian 2015 general elections and beyond. International Journal of Humanities and Social Science Invention, 5(5): 20-26.

Abubakar, A. (2015) History of Elections in Nigeria from Independence 2015 General Elections. Published on People's Daily on Saturday March 28th, 2015. Accessed on the 23rd of June, 2017 from www.peoplesdailyng.com/history-of-elections-in-nigeria-from-independence/. 
Adebayo, A.A. (2013) Youth's unemployment and crime in Nigeria: A nexus and implication for national development. International Journal of Sociology and Anthropology, 5(8): 350-357.

Agba, M.S. (2011) Political thuggery and democratic dividends in Nigeria: an empirical study. Higher Education of Social Science, 1(1): 58-65.

Agbaje, A.A.B., Onwudiwe, E. \& Diamond, L. (2004) Introduction: Between the Past and the Future. In Agbaje, A.A.B. et al. (Eds.), Nigeria's Struggle for Democracy and Good Governance. Ibadan: Ibadan University Press: $\mathrm{xix}-\mathrm{xxi}$.

Akande, S.O. \& Okuwa, O.B. (2009) Empowering Nigerian Youths for the 21st Century. NISER Occasional Paper, No. 3, NISER, Ibadan, Nigeria.

Akokuwebe, M.E. \& Okunola, R.A. (2015) Demographic transition and rural development in Nigeria. Developing Country Studies, 5(6): 90-102.

Ali, Y.O. (2015) Security: A panacea to peaceful 2015 general elections. Being a lecture delivered at the peace and conflicts studies students' association 2015 peace week at the Trenchard Hall, University of Ibadan.

Amenaghawon, J. (2015) 2015 Nigeria elections: The gains, the challenges and the lessons. Accessed on the 23rd of June, 2017 from www.opinionpremiumtimesng.com/2015/24/2015-nigeria-elections-the-gains-the-challenges-and-the-lessons-by-joseph-amenaghawon/.

Anifowose, R. (1982) Theoretical explanation of political violence. In violence and politics in Nigeria: The Tiv and Yoruba Experience. NOK International Publishers, Enugu, Nigeria, 1-30.

Araya, M. (2012) Generating Jobs for the Youths: A Priority agenda for Africa. University of Bengamo. Accessed on February 25th, 2015 from www.adapt.it.

Arowosegbe, J. (2009) Violence and National Development in Nigeria: The political Economy of Youth Restiveness in the Niger Delta. Review of African Political Economy, 36(122): 575-594.

Awopeju, A. (2011) Election rigging and the problem, of electoral act in Nigeria. Afro Asian Journal of Social Sciences, 2(2, 4): IV: 1-17.

Bernburg, J.G. (2002) Anomie, social change and crime. A theoretical examination of institutional-anomie theory. Brit. J. Criminol.; 42: 729742.

Blackwell, A. \& Duarte, P. (2014) Violence, crime and social exclusion. Accessed on the 22nd of June, 2017 from hhtp://adamblackwell.wordpress.com.

CIA World Factbook (2017) Nigeria People 2017 - Population. Accessed on the 23rd of June, 2017 from www.theodora.com/wfbcurrent/nigeria/nigeria_people.html.

Cramer, C. (2010) Unemployment and participation in violence. World Development Report 2011 Background Paper. School of Oriental and African Studies, London. 
Diana-Abasi, I.F. (2015) Solving the problem of poor quality of university graduates in Nigeria-a proposed holistic approach. British Journal of Education, 3(7): 52-70.

Hooker, J.N. (2011) Moral Implications of Rational Choice Theories. Tepper School of Business, Carnegie Mellon University, 1-19.

Human Rights Watch (HRW) (2003) Testing Democracy/Political Violence in Nigeria. Accessed on the 22nd of June, 2017 from http://www.hrw.org/report/2003/04/01/testing-democracy/political-violence-nigeria.

Inokoba, P.K. \& Maliki, A.E. (2011) Youths, electoral violence and democratic consolidation in Nigeria: the Bayelsa State experience. Anthropologist, 13(3): 217-225.

International Labour Office (ILO) (2010) Global employment trends for youth, August 2010: special issue on the impact of the global economic crisis on youth International Labour Office. - Geneva: ILO.

International Labour Office (ILO) (2012) The youth employment crisis: time for action. International Labour Conference, 101st Session, Fifth item on the agenda. International Labour Office, Geneva. 1-20.

International Labour Office (ILO) (2013) Global Employment Trends for Youth - 2013: A Generation at Risk. ILO, Geneva. Accessed on April 8th, 2015 from http://www.ilo.org/empelm/pubs/WCMS_165455/lang--en/index.htm.

Jubenkanda, R.R. (2003) Labour Economics. Zimbabwe Open University. Harare.

Kararach, G., Hanson, K.T. \& Léautier, F.A. (2011) Regional Integration Policies to Support Job Creation for Africa's Burgeoning Youth Population. African Capacity Building Foundation. 3-7.

Ladan-Baki, I.S. (2016) Electoral violence and 2015. Electoral violence and 2015 General Elections in Nigeria. Global Journal of Human Social Science: (F) Political Science, 6(1): 22-23.

Lamido, S. (2013) Unemployment fueling insecurity in Nigeria. Punch Newspaper, July 23, 2013, 1-3.

Lawanti, K.D. (2009) Curbing thuggery, hooliganism in the 2011 elections. Accessed on October 13th, 2015 from www.modernghana.com/news/220796/1/curbing-thuggery-hooliganism-in-the-2011-elections.html.

Levin, J. \& Milgrom, P. (2004) Introduction to Choice Theory. 1-25.

Mago, S. (2014) Urban youth unemployment in Africa: whither socioeconomic problems. Mediterranean Journal of Social Sciences, 5(9): 3340.

Merton, R.K. (1938) Social structure anomie. American Sociological Review, 3(5): 672-682.

Merton, R.K. (1957). Social theory and social structure. Revised and enlarged edition. New York: Free Press of Glencoe, IL.

Merton, R.K. (1968) Social Structure and anomie in Social theory and social structure. New York. Free Press, 216-217. 
Messner, S.F. (2014) Merton, Robert K: Social Structure and Anomie. In Encyclopedia of Criminological Theory. In Francis T. Cullen \& Pamela Wilcox (Eds.). SAGE Publications, Inc., Thousand Oaks, 4-17.

Momoh, A. (2000) Youth culture and area boys in Lagos. In Jega, A. (Ed.). Identity transformation and identity politics under structural adjustment in Nigeria. Sweden, ElandersGotab.

National Youth Policy, 2009. Nigeria National Youth Policy Documents. Accessed on 23rd of June, 2017 from https://www.k4health.org/toolkits/youthpolicy/nigeria-national-youth-poli-cy-and-strategic-plan-action.

Nigerian Bureau of Statistics (NBS) (2016) NBS: Another 1.5 million Nigerians became unemployed in 2016. Accessed on the 22nd of June, 2017 from https://www.thecable.ng/nbs-another-1-5m-nigerians-becomeunemployed-2016.

Obadan, M.I. \& Odushola, A.F. (2001) Productivity and unemployment in Nigeria. Ibadan: National Centre for Economic Management and Administration, 3-8.

Obi, C. (2006) Youth and the generational dimension to struggles for resource control in the Niger Delta: prospects for the nation state project in Nigeria. CODESRIA, Dakar, Senegal.

Okafor, E.E. (2011) Youth unemployment and implications for stability of democracy in Nigeria. Journal of Sustainable Development in Africa, 13(1): 5-8.

Omeje, K. (2007) Youths, conflicts and perpetual instability in Nigeria. Accessed on 9th of October, 2015 from www.hollerafrica.com.

Oriakhi, D. (2012) The impact of national security on foreign direct investment in Nigeria: an empirical analysis. Journal of Economics and Sustainable Development, 3(13): 25-42.

Sembonja, H.H.H. (2007) The Youth Employment in East Africa: An Integrated Labour Market Perspective. African Integration Review, 1(2): 45-68.

Simiyu, J. \& Lenah, S. (2012) Nature and Type of Government and NGO Interventions in Curbing Unemployment and Underemployment of Urban Youth in Kenya. Journal of Emerging Trends in Educational Research and Policy Studies (JETERAPS), 3(5): 730-736.

Sommers, M. (2013) Youth, war and urban Africa: challenges, misunderstandings, and opportunities. In Blair A. Ruble, Joseph S. Tulchin, Diana H. Varat with Lisa M. Hanley, 2003. Youth explosion in developing world cities: approaches to reducing poverty and conflict in an urban age. Woodrow Wilson International Center for Scholars, Washington, D.C. Accessed on April 10th, 2016 from www.wilsoncenter.org.

Ukkiwo, U. (2007) From pirates to militants: a historical perspective on antistate and anti-oil company mobilization among the Ijaw of Warri, Western Niger Delta. African Affairs (London), 106(425): 587-610. 
Umoru, H. (2015) 20m Nigerian Youths unemployed - FG. Vanguard Nigeria News, $1-3$.

UNESCO (2003) Youth Unemployment Meeting the Needs of Youth: An Annotated Bibliography of Research. Wealthiest Nations. Conservation International, Cemex.

Usoro, E.B. (2010) Developing human resources in Tertiary Business education youth empowerment and national development in Nigeria. Review of Higher Education in Africa, 2(1): 1-8.

Wyn, J. and White, R. (1997) Rethinking youth. Sage; London.

Yau, Y. (2000) The youth, economic crisis and identity transformation: the case of Yandaba in Kano. In Jega (Ed.). Identity transformation and identity politics under structural adjustment in Nigeria. Nordic Africa institute and center for research and documentation, Uppsala and Kano. 